\title{
CNDO-109-activated Allogeneic Natural Killer Cells
}

National Cancer Institute

\section{Source}

National Cancer Institute. CNDO-109-activated Allogeneic Natural Killer Cells. NCI

Thesaurus. Code C99898.

A preparation of non-interleukin-2 primed, tumor activated allogeneic natural killer (NK) cells with potential immunostimulating activity. The allogeneic NK cells obtained from a first or second degree relative of the patient are co-incubated with a lysate from the CTV-1 cell line, a minimally differentiated myeloid line derived from an acute myelogenous leukemia patient. Infusion of CNDO-109-activated allogeneic NK cells may be able to lyse and destroy NK-resistant tumor cells and a broad spectrum of tumor cells. 